\title{
Salesforce Automation (SFA) Ecosystem: Functionalities, Challenges and Benefits of Adoption of SFA
}

\author{
Sarika Chaudhary \\ Department of computer science and engineering, Amity University \\ Email: sarikacse23@gmail.com
}

\begin{abstract}
In today's competitive and intense market, Sales force automation (SFA) let us to judge the upcoming business and new endeavors so we can successfully seek after the most important opportunities. SFA permits managers to manage and structure data related to sales in many ways. It is a computer based system with the involvement of information technology, that allows management to keep track of sales, prospective customers, oversee contacts, control client relations, plan, and monitor and control various process and meetings, estimate projects and examines representative execution. These expect to expand the productivity and adequacy of a business group in their served markets. SFA ecosystem is a combination of hardware, software and analogous services. This research summarizes various aspects on SFA such as what are the reasons behind the growth of SFA in the organizations? Who are the global leaders in SFA market? The paper concludes with the benefits and key factors for the success of SFA projects followed by conclusion and sets out a plan for additional research.
\end{abstract}

Index Terms-CRM, Sales force automation, sales force management, stakeholders, technology.

\section{INTRODUCTION}

Computerization of assignments using data innovation is a compelling strategy to move forward hierarchical effectiveness. Despite the fact that showcasing was among one of the main practical territories to receive data innovation, SFA is a technology that is offering support to representatives and managers since 90's but it is largely adopted by the markets leaders from last decade, to enhance the efficiency and effectiveness of the organization. Sometimes the researchers are misguided by the judgement that contact management and sales force automation is same. No, this not true. SFA isn't contact management; even SFA and CRM are not same. Both have some common attributes but are used by the managers for achieving unique targets. SFA is a product arrangement that computerizes certain business capacities and undertakings. It gives data about leads, contacts, records or clients, openings in your pipeline and anticipating data to give some examples. Other helpful capacities in a decent SFA framework are things like programmed lead task, enormous arrangements alarm and bolster for deals work process. As should be obvious these capacities make a salesman more productivity. We should investigate a couple of key part of SFA and how it can empower a sales representative to enhance its efficiency[1].

SFA can be defines as the use of technology to improve the sales of organization by providing the speedy access to various sales trends to the salespersons and the top level management at regular Interval of time. All SFA programming is planned with the goal that relevant client related information can be caught, put away, dissected and circulated to sales representatives and deals directors with the end goal for them to wind up more successful or efficient in the quest for their
goals.SFA software dramatically affects the way sales are performed. As indicated by ongoing investigation sales representatives utilizing a computerized arrangement expanded their discussion time by $87 \%$ and had $16 \%$ higher contact and change rates than their associates. Robotization of sales has unquestionably made salesmen efficient, however a few people stress that outsourcing excessively to a machine can make businesses indifferent and along these lines less persuading for potential purchasers. In the event that business people lean vigorously on bland email impacts, for instance, they chance baffling and distancing purchasers. They additionally may end up self-satisfied and lose essential abilities like basic examination of prospects' agony focuses. By actualizing these arrangements deliberately, sales representatives cannot just hold their capacity to shape associations with prospects, yet additionally upgrade it [2].Timing is a critical segment of offers achievement. Deals compel robotization programming helps business people stay aware of purchasers as they progress through the distinctive phases of their adventure. Programming helps increment the odds of making an underlying association and guarantees you keep up the association with reliable touch focuses. After the underlying association is set up, the business procedure turns into a matter of moving a colleague into a genuine relationship. Innovation creates relevant discussions at various levels to construct significant connections [3]. Once the reps of the organizations have associated with somebody from an objective organization, it's a great opportunity to penetrate down into how that individual purchases. For a more individual touch, innovation can pull identity data to make every association much more 
International Journal of Research in Advent Technology, Vol.7, No.5, May 2019

E-ISSN: 2321-9637

Available online at $w w w$.ijrat.org

individualized. Henceforth by having SFA constrain one can upgrade own association with his clients.

\section{SFA ECOSYSTEM}

The SFA environment is comprised of three parts: SFA arrangements suppliers, equipment and framework sellers, and related specialist organizations. The innovation empowers organizations to gather, store, break down, convey and utilize client related information for managerial purposes SFA programming from arrangements suppliers empowers employees and their directors to oversee deals pipelines, track contacts and configure items, among numerous different things. SFA programming likewise gives reports to representative of the organizations [3].

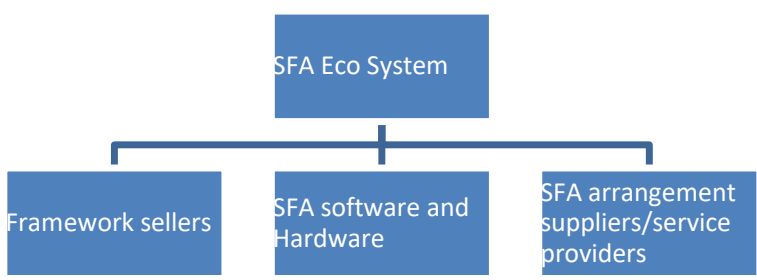

Fig. 1. SFA Eco System

\section{SFA FRAMEWORK SELLERS}

Some SFA suppliers are pros center around a specific usefulness of SFA. They go up against big business arrangement suppliers (who give a total scope of business arrangements like enterprise and resource planning, customer relationship management, SCM etc) and some framework sellers of CRM which includes SFA modules [4].

The CRM arrangement providers additionally concoct configurators, the item engines that empower the clients to tweak their items. Since the configurators help construct tweaked items, the weight on the salespersons of taking care of complex information without blunders is diminished. In this way, their readiness cost is also lessened. Classification of SFA vendors is shown below in fig 2 .

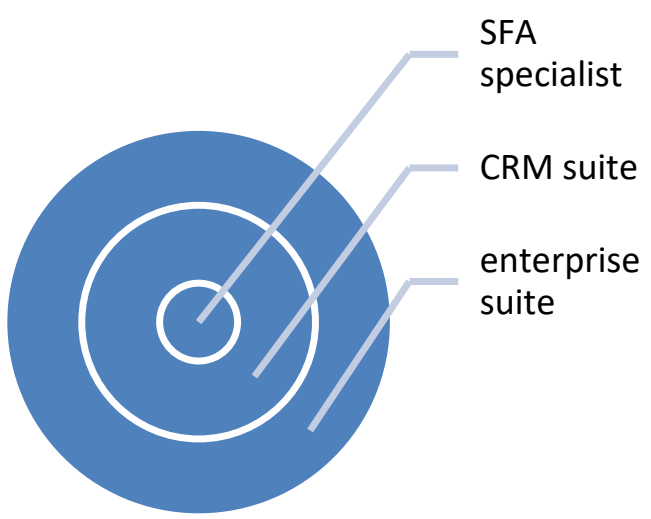

Fig.2. Classification of SFA vendors
Table 1. Example of SFA specialist in global market

\begin{tabular}{|l|l|l|}
\hline $\begin{array}{l}\text { SFA } \\
\text { specialists }\end{array}$ & $\begin{array}{l}\text { Cyberforms, } \\
\text { EZroute, } \\
\text { Selectica }\end{array}$ \\
\cline { 1 - 2 } SFA as part of CRM suite & $\begin{array}{l}\text { Salesforce.com , } \\
\text { Apptivo, } \\
\text { Freshsales, } \\
\text { Pipeliner CRM }\end{array}$ \\
\hline $\begin{array}{l}\text { SFA as a part of enterprise } \\
\text { suite }\end{array}$ & $\begin{array}{l}\text { SAP, Epicor, } \\
\text { Fourth Shift, } \\
\text { Deltek, Base , } \\
\text { Chime }\end{array}$ \\
\hline
\end{tabular}

\section{SFA Software and Hardware}

In this the time of developing organizations, the SFA equipment and foundation must have the capacity to adapt up to expansive number of clients for long time. In house salespersons are open to utilizing work area or PCs the outside salespersons of a business favor tablets, laptop, palmtop etc. In such extensive variety of gadgets, the SFA innovation ought to be equipped for executing on each kind of gadget. If there should be an occurrence of worldwide business, the salespersons and administrators over every one of the outlets need to get to the CRM database countless. In such circumstance, the SFA innovation ought to be outfitted with taking care of far off correspondence or information exchange over remote and quick media [4].

\section{SFA Services}

The administrations part of the SFA environment is exceptionally differing. At the point when a business compel mechanization venture is attempted, benefit expenses may significantly add to general extend consumption. SFA venture pioneers might purchase administrations from suppliers that re-build offering forms, oversee ventures, prepare salesmen, and counsel on authoritative structure or on the other hand direct client portfolio investigation. Specialist organizations can contribute significantly both to SFA venture costs and to the likelihood of accomplishment [5].

\section{Various Functionalities of SFA}

1. Account administration: It offers deals agents and supervisors a finish perspective of the client relationship including contacts, contact history, finished exchanges, current requests, shipments, enquiries, benefit history, openings and citations. This permits deals agents and record administrators to monitor every one of their commitments in regard of each record for which they are capable, regardless of whether this is a chance to be shut, a request or an administration enquiry.

2. Event administration: It empowers to design the occasions, for example, gathering, public exhibition, online courses and workshops, gatherings, and so on with clients or different 
International Journal of Research in Advent Technology, Vol.7, No.5, May 2019

E-ISSN: 2321-9637

Available online at $w w w$.ijrat.org

accomplices. It highlights occasion date-book, occasion reports, and so forth.

3. Contact and activity administration: It refers customers' contact numbers, Email ID, address, contact preferences, etc., for maintaining contacts by creation, updating, tracking appointments and contacts, etc.

4. Order and contract administration: its usefulness empowers delegates and chiefs to make, track, advance, quicken, screen and control contracts with clients. Contract administration deals with an agreement's life expectancy by shortening endorsement cycles for contracts, recharging contracts sooner and diminishing regulatory expenses. The product may utilize security controls to guarantee just endorsed individuals approach contracts.

5. Incentive administration: It is an issue for deals administrators who utilize commissions to lift, direct and compensate deals agents 'endeavor's. In numerous organizations, commissions are figured utilizing independent spreadsheets. At the point when part of a deals drive computerization arrangement, impetus administration dispenses with the need to reenter or exchange information from spreadsheets, prompting better perceivability, exactness and higher efficiency. Motivator administration applications can be connected into back-office finance applications that robotize instalment.

6. Document administration: Organizations produce and utilize numerous records as they pitch to clients, for instance pamphlets, item specifications, value records, aggressive examinations and layouts for getting ready citations. Report administration programming enables organizations to deal with these archives, keep them current and guarantee that they are accessible to agents what's more, supervisors when required. A few frameworks enable all archives to be 'connected' to the record or contact, consequently encouraging speedier and full review of past communications.

7. Lead administration: enables organizations to make, appoint and track deals leads. Leads either lapse or change over into qualified openings. Client defined rules enable prompts be assigned to delegates and account chiefs on different factors. It takes into account more impartial workload dispersion over a business group, and uses security controls to guarantee that agents can just access their own leads.

8. Pipeline administration: Pipeline administration is the way toward dealing with the whole deals cycle, from distinguishing prospects, assessing deals potential, overseeing leads, and gauging deals, starting and keeping up client connections, directly through to conclusion. It depends on exact, state-of-the-art opportunity data, for example, the potential size and close date for every opportunity.
9. Opportunity administration: Opportunity administration programming empowers delegates furthermore, directors to make an open door record in the database and screen advance against a predefined offering procedure. Sales representatives take after the ventures as though following an agenda, guaranteeing that all open doors are dealt with reliably. Deals delegates can see their own chances connected to extra data, for example, contacts, exercises, items, proposition, ventures, introductions, citations, contenders, assessed income, cost of offers, likelihood of conclusion, deals stage etc. Opportunity administration usefulness enables agents to gauge their future rewards or commissions. Administrators would then be able to get gives an account of the advance of chances as they move towards conclusion, separated by sales representative, domain sort, date or other criteria [7].

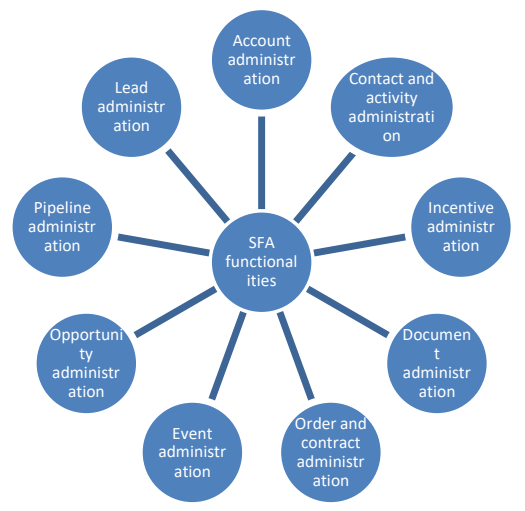

Fig.3. Functionalities of SFA

\section{SFA Adoption by Organization}

Framework sellers and specialists guarantee a number of benefits from SFA usage, including accelerated income, exact detailing, shorter deals cycles leading to speedier stock turnover, improved customer relations, increased sales income enhanced salesperson productivity, piece of the overall industry development, lessened cost-of-offers, more closing opportunities and enhanced profitability. These hard results can be complemented by milder results, for example, less revise, more timely data, and better quality management reports.

Usually motivation to adopt SFA by an organization is followed by a process, which includes two stages:

1. Senior management decision to invest in SFA.

2. Employees and managers decision to use SFA.

\section{CHALLENGES, ADVANTAGES AND SUCCESS FACTORS}

Generally five essential entanglements in Sales Force Automation (SFA) frameworks, any of which can wreck a product usage or cause critical issues. Very regular issues incorporate absence of purchase 
in, inappropriate or inadequate information input, a non-responsive framework because of moderate system or restrictions of access to the framework, poor preparing and absence of appropriate customization [6].

- Inadequate sales management employees.

- Lack of proper training of staff.

- Incomplete information regarding customers.

- Improper customization of forms, menus etc.

- Forcing the staff to upgrade with proper orientation.

\section{Advantages of SFA}

Below are the benefits of sales force automation software from the view points based on different types of stakeholders [7].

Table 2: Benefits according to stakeholders

\begin{tabular}{|l|l|}
\hline $\begin{array}{l}\text { Framework } \\
\text { seller point of } \\
\text { view }\end{array}$ & $\begin{array}{l}\text { Enhanced customer relationship, staff } \\
\text { efficiency and effectiveness and large } \\
\text { revenue }\end{array}$ \\
\hline $\begin{array}{l}\text { Salesperson } \\
\text { point of view }\end{array}$ & $\begin{array}{l}\text { Improved closing opportunities, } \\
\text { reduced cycle time, easy tracking of } \\
\text { sales cycle }\end{array}$ \\
\hline $\begin{array}{l}\text { Manager } \\
\text { point of view }\end{array}$ & $\begin{array}{l}\text { Improved productivity and enhanced } \\
\text { reporting }\end{array}$ \\
\hline $\begin{array}{l}\text { Business } \\
\text { point of view }\end{array}$ & $\begin{array}{l}\text { Higher win rates, better customer } \\
\text { relationships, improved confidence of } \\
\text { customer in organization }\end{array}$ \\
\hline
\end{tabular}

\section{SFA Success Factors}

It is certain that SFA ventures can be both costly and tedious. Expenses are acquired as project pioneers purchase item or administration from one or a greater amount of the SFA eco-framework individuals [8].

There are numerous factors on which we can assure the success of sales force automation. They are discussed below:

1. Project based factors

2. Inter and intra personal factors

3. Technical factors

4. Organizational environment based factors

Table 3: Sales force automation success factors

\begin{tabular}{|l|l|}
\hline $\begin{array}{l}\text { Project based } \\
\text { factors }\end{array}$ & $\begin{array}{l}\text { Structured project plan, } \\
\text { involvement of users and } \\
\text { customers, effective } \\
\text { deployment of implementation } \\
\text { team, regular sessions for } \\
\text { effective team training. }\end{array}$ \\
\hline $\begin{array}{l}\text { Inter and intra } \\
\text { personal factors }\end{array}$ & $\begin{array}{l}\text { Accurate management to match } \\
\text { the level of user expectation, } \\
\text { information sharing at various } \\
\text { levels of management, } \\
\text { trustworthiness between the } \\
\text { employees adaptive nature of } \\
\text { the employees towards } \\
\text { technology, skills to use } \\
\text { computers easily. }\end{array}$ \\
\hline $\begin{array}{l}\text { Data correctness, timely } \\
\text { availability of data low } \\
\text { development cost etc. }\end{array}$ \\
\hline
\end{tabular}

\begin{tabular}{|l|l|}
\hline $\begin{array}{l}\text { Organizational } \\
\text { environment }\end{array}$ & Regular orientation of \\
based factors & customers, motivational talks \\
& $\begin{array}{l}\text { for the employees, regular } \\
\text { encouragement of employees } \\
\text { etc. }\end{array}$ \\
\hline
\end{tabular}

\section{CONCLUSION AND FUTURE SCOPE}

Sales force automation framework brings the two favorable circumstances and weaknesses to sales representative. In some ways, SFA framework encourages salesman to conquer their issues, for example, client relationship administration, offering process, knowing better of their rivals and clients. Rather than continue offering and redesigning the old items, salesman will have the capacity to grow new item in the wake of utilizing SFA framework. This is on the grounds that the sales representative will have the capacity to know their clients' decisions through SFA. Their organization's product offering can be extended and become more extensive. Thus there will have more options for clients to pick with the organization's image name items. At the point when there are more selections of items accessible to decide for clients, there will be more clients come and buy and devour the organization's items that bit by bit increment the organization income.

\section{REFERENCES}

[1] Domfeh, Henry \& Kusi, Lawrence \& Kwamena, Minta \& Nyarku, Kwamena \& D Hunsaker, William \& Ameyaw, Henry \& D Nyarku, William \& , Hunsaker. (2018): The Impact of Sales Force Automation System on Quality Service Delivery and Sales Reporting among Micro and Small-Sized Enterprises in Kumasi Metropolis, Ghana.

[2] Ranjan, Jayanthi \& Puri, Sandeep. (2011): Sales force automation. Research agenda. Int. J. of Value Chain Management. 5. 141 - 150.

[3] Robert L. Engle, Michael L. Barnes, (2000): Sales force automation usage, effectiveness, and cost-benefit in Germany, England and the United States. Journal of Business \& Industrial Marketing, Vol. 15 Issue: 4, pp.216-241

[4] Fisher, C. (2017): New Technologies for Mobile Salesforce Management and CRM. American Journal of Industrial and Business Management, 7, 548-558.

[5] Agnihotri, R., and Rapp, A. A., (2010): Effective Sales Force Automation and Customer Relationship Management: A Focus on Selection and Implementation. Business Expert Press.

[6] Boujena, O., Johnston, W. J., and Merunka, D. R., (2009):The Benefits of Sales Force Automation: A Customer's Perspective. Journal of Personal Selling \& Sales Management, Vol. (22), No. 2.

[7] Buttle, F., Ang, L., and Iriana, R., (2006): Sales Force Automation: Review, Critique, Research 
International Journal of Research in Advent Technology, Vol.7, No.5, May 2019

E-ISSN: 2321-9637

Available online at www.ijrat.org

Agenda. International Journal of Management Reviews, Vol. 8 (4) 213-231.

[8] Earl D. Honeycutt Jr., Tanya Thelen, Shawn

T. Thelen, Sharon K. Hodge: Impediments to sales force automation Industrial Marketing Management, Volume 34, Issue 4, May 2005, pp. 313-322. 